\title{
CONGRATULATIONS on the occasion of jubilee TO ZAVEN GRIGOR'EVICH TER-MARTIROSYAN -
}

Doctor of Engineering Sciences, Professor, Distinguished Figure of Science of the Russian Federation, Chairman of the Moscow Division of the Russian Society for Soil Mechanics, Geotechnics, and Foundation Engineering, and Chief Scientific Researcher at the Geotekhnika Center for Science and Education at the Moscow State University of Civil Engineering

Zaven Grigor'evich Ter-Martirosyan is the leading specialist in the field of theoretical and applied geomechanics. His teachers were N.A. Tsytovich and G.I. Ter-Stepanyan. Over a 15-year period, he successfully managed the Department of Soil Mechanics and Foundation Engineering at the Moscow State University of Civil Engineering (MGSU), which is a leading department that trains geotechnical specialists in our country. Currently, he is one of the most successful scientific supervisors at the university.

Zaven Grigor'evich's research on theoretical and applied geomechanics problems, including consolidation and creep in clay soil, have enabled the development of the experimental and theoretical foundations of quantitative forecasting of the stress-strain state of soil mass beds.

Under his leadership, an integrated program for the numerical assessment of the stress-strain state of soil masses, that are the base and environment of different structures, has been developed at the Geotekhnika Center for Science and Engineering at MSUCE. These developments have found wide application in the scientific follow-up to construction projects, especially critical high-rise buildings being erected in deep excavation pits. In each large organization related to soil mechanics or foundation engineering, there is a member of the staff who was either Zaven Grigor'evich Ter-Martirosyan's student or subordinate, or whose scientific and technical efforts were reviewed by him.

Zaven Grigor'evich is the author or coauthor of five monographs, three textbooks, more than 320 publications, and 40 inventions. His monograph "Rheological Properties of Soil and the Design of Structure Beds" has been translated into English and published by the Oxford University Press.

Z.G. Ter-Martirosyan activities include ongoing community involvement. He is the chairman of a specialized committee for the conferral of the scientific degrees of Doctor and Candidate of Engineering Sciences at MSUCE in the concentrations of "Foundation Engineering and Underground Structures" and "Geomechanics, Rock Disintegration, Mine Aerogasdynamics, and Mining Thermophysics." $\mathrm{He}$ is a member of the presidium of the Russian Society for Soil Mechanics, Geotechnics, and Foundation Engineering, the chairman of the Moscow division of that organization, a full member of the International Institute of Civil Engineers (UK), a member of the editorial board of the journals "Soil Mechanics and Foundation Engineering," "Engineering Geology," "Geotekhnika," and "Vestnik MGSU," and an expert member of Moscow municipal committees on foundation engineering and underground structures affiliated with the Moscow city government. Zaven Grigor'evich is an Honored Builder and Honored Energy Worker of the Russian Federation.

Dear Zaven Grigor'evich,

The Russian Society for Soil Mechanics, Geotechnics, and Foundation Engineering, the editorial staff and editorial board of this journal, students, and colleagues sincerely congratulate you on the occasion of your jubilee and wish you good health, many years of fruitful work, and widely recognized new successes!

Translated from Osnovaniya, Fundamenty i Mekhanika Gruntov, No. 5, p. 18, September-October, 2016. 